\title{
SARS-CoV-2 intervened by NSAIDs: A network pharmacology approach to decipher signaling pathway and interactive genes
}

Ki Kwang Oh

Kangwon National University

Md. Adnan

Kangwon National University

Dong Ha Cho ( $\square$ chodh@kangwon.ac.kr)

Kangwon National University

\section{Research Article}

Keywords: Non-Steroidal Anti-Inflammatory Drugs, COVID-19, MAPK8-MAPK10-BAD, 6MNA-RofecoxibIndomethacin, RAS signaling pathway, Network pharmacology

Posted Date: November 30th, 2020

DOl: https://doi.org/10.21203/rs.3.rs-111615/v1

License: (a) (1) This work is licensed under a Creative Commons Attribution 4.0 International License. Read Full License 


\section{Abstract}

Background: Non-Steroidal Anti-Inflammatory Drugs (NSAIDs) showed promising clinical efficacy toward COVID-19 patients as painkillers and anti-inflammatory agents. However, the prospective anti-COVID-19 mechanisms of NSAIDs are not evidently exposed. Therefore, we intended to decipher the most potent NSAIDs candidate(s) and its novel mechanism(s) against COVID-19 by network pharmacology.

Method: FDA (U.S. Food \& Drug Administration) approved twenty NSAIDs were used for this study. Genes related to selected NSAIDs and COVID-19 related genes were identified by the Similarity Ensemble Approach, Swiss Target Prediction, and PubChem databases. Venn diagram identified overlapping genes between NSAIDs and COVID-19 related genes. The interactive networking between NSAIDs and overlapping genes was analyzed by STRING. RStudio plotted the bubble chart of KEGG pathway enrichment analysis of overlapping genes. Finally, the binding affinity of NSAIDs against target genes was determined through molecular docking analysis.

Results: Geneset enrichment analysis exhibited 26 signaling pathways against COVID-19. Inhibition of proinflammatory stimuli of tissues and/or cells by inactivating RAS signaling pathway was identified as the key anti-COVID-19 mechanism of NSAIDs. Besides, MAPK8, MAPK10, and BAD genes were explored as the associated genes of the RAS. Among twenty NSAIDs, 6MNA, rofecoxib, and indomethacin revealed promising binding affinity with the highest docking score against three identified genes, respectively.

Conclusions: Overall, our proposed three NSAIDs (6MNA, rofecoxib, and indomethacin) might block the RAS by inactivating its associated genes, thus may alleviate excessive inflammation induced by SARSCoV-2.

\section{Introduction}

An initial outbreak of pneumonia caused by unknown etiology was first reported at Wuhan in Hubei Province, China, and alerted to the World Health Organization (WHO) by the Wuhan Municipal Health Commission on 31 December $2019^{1}$. Later, the infectious disease experts detected severe acute respiratory syndrome coronavirus 2 (SARS-CoV-2), can rapidly transmit from person to person through interaction or respiratory droplets ${ }^{2}$. As a consequence of its tremendous spread in the world, WHO announced a changing level from epidemic to pandemic disease (COVID-19) on March 11, $2020^{3}$. Although the symptoms are identical to pneumonia, however, a considerable number of COVID-19 infected patients showed no physical sign, thus can transmit the virus to others, as silently spread ${ }^{4}$.

Due to the unavailability of a reliable vaccine, clinicians are utilizing anti-viral drugs and NSAIDs as a significant viable option for COVID-19 patients ${ }^{5}$. A recent study has reported that use of NSAIDs is safe for COVID-19 treatment without exposing specific negative side effects ${ }^{6}$. Though there is a lack of evidence whether combined NSAID s treatment could worsen COVID-19 symptoms ${ }^{7}$, but researchers suggested that anti-inflammatory therapies might suppress the fatal cytokine storm of COVID-19 patients 
${ }^{8}$. Additionally, WHO announced that no evidence of unwanted side effects was reported, particularly the risk of death with the administration of NSAIDs in COVID-19 patients ${ }^{9}$.

Commonly, NSAIDs are used to treat diverse anti-inflammatory symptoms due to its good therapeutic efficacy ${ }^{10}$. However, one potential drug of interest is indomethacin which possesses both antiinflammatory and antiviral properties. Its antiviral potentiality was first identified in 2006 during the outbreak of SARS-CoV ${ }^{11}$ and subsequent attribution was also observed against SARS-CoV-2 ${ }^{12}$. A study on canine coronavirus (in vitro) revealed that indomethacin could significantly suppress virus replication, thus protecting host cell from virus induced damage. Similar antiviral effect was also observed during in vivo assessment where normal anti-inflammatory dose was found very effective ${ }^{12,13}$. Although there are many NSAIDs which may have possible therapeutic interventions against COVID-19, lack of scientific evidence has limited their broad application to COVID-19 patients. Hence, we aimed to identify the most potent NSAIDs and their mechanism(s) against COVID-19 through network pharmacology.

Network pharmacology can decode the mechanism(s) of drug action with an overall viewpoint, which focuses on pattern changing form "single protein target, single drug" to "multiple protein targets, multiple drugs" 14 . Currently, network pharmacology has been extensively utilized to explore multiple targets and unknown additional mechanism(s) against diverse diseases ${ }^{15}$. In this research, network pharmacology was applied to investigate the most potent NSAIDs and their novel mechanisms of action against COVID19. Firstly, a total of 20 approved NSAIDs was selected via using public websites. The 20 NSAIDs and COVID-19 related genes were also identified using public databases. Next, the selected overlapping genes were discovered as target genes for analyzing anti-COVID-19. Finally, pathway enrichment analysis was performed to reveal the mechanism(s) of the most potent NSAIDs against COVID-19. Figure 1 shows overall workflow.

\section{Results}

\section{Information of NSAIDs}

A total of twenty FDA approved NSAIDs was selected. Table 1 and Figure 2 display the chemical information and structure of these NSAIDs. Among the twenty NSAIDs, nineteen NSAIDs were found as active drug and one "nabumetone" was a prodrug and its metabolite form is 6-methoxy-2-naphthylacetic acid (6MNA). Figure 3 shows nabumetone oxidized into 6MNA.

\section{NSAIDs linked to the 781 genes or COVID-19 related genes}

By screening from two public databases (SEA and STP), a total of 781 NSAIDs related genes were identified (see Supplementary Table S1). The overlapping genes (228 genes) selected from the two databases were shown (see Supplementary Table S2). Figure 4 displays the result of the overlapping genes. From the PubChem database, 466 COVID-19 related genes were identified (see Supplementary 
Table S3). The 26 overlapping genes were extracted between the 228 overlapped genes and 466 COVID19 related genes (see Supplementary Table S4). Figure 5 shows the result of overlapping genes.

\section{Pathway enrichment analysis of overlapping genes and identification of significant genes against COVID- 19}

Figure 6 displays the identified overlapping 26 genes were linked closely to each other through utilizing STRING. Based on the Kyoto Encyclopedia of Genes and Genomes (KEGG) pathway enrichment analysis with "Homo sapiens" mode, 26 signaling pathways from the 26 genes were revealed against COVID-19. Figure 7 shows the signaling pathways were plotted in the bubble chart through Rstudio. Table 2 provides the detailed description of the 26 signaling. Figure 8 shows that both MAPK8 and MAPK10 linked to 22 out of 26 signaling pathways, were determined as hub genes of NSAIDs against COVID-19. Coincidently, both MAPK8 and MAPK10 play major roles in all of the 22 signaling pathways by the RAS signaling pathways, suggesting that BAD (Bcl-2-associated death promoter) gene and the two hub genes (MAPK8 and MAPK10) are associated with the RAS signaling pathway against COVID-19. The interactions between NSAIDs and each gene were visualized with RStudio (see Supplementary Figure S1).

\section{Affinity binding energy score on three genes of the most potent NSAIDs against}

\section{COVID-19}

From the SEA and STP databases, it was revealed that MAPK8 gene is associated with three NSAIDs (6MNA, Mefenamic acid, and Etodolac), MAPK10 gene is related to twelve NSAIDs (Mefenamic acid, Naproxen, Tolmetin, Fenoprofen, Ketorolac, Ketoprofen, Ibuprofen, Flurbiprofen, Oxaprozin, Sulindac, Diclofenac, and Rofecoxib), BAD gene is involved with two NSAIDs (6MNA and Indomethacin).

Figure 9 displays the molecular docking was performed to evaluate the binding mode of these three genes against their associated NSAIDs, respectively, and the docking figures are depicted in Molecular docking score of M1-M3 on MAPK8 protein (PDB ID: 4YR8) was analyzed in the "Homo Sapiens" mode. Based on the docking score, the order of priority of binding energy is given: M1>M2>M3. The three-affinity binding energy of M1-MAPK8, M2-MAPK8, and M3-MAPK8 indicated -7.1, -6.4, and -6.3 kcal/mol, respectively. The 6MNA (M1) had the strongest affinity on MAPK8. Interaction analysis of best-docked compound namely "6MNA" resulted one hydrogen bond (Lys-218) and seven hydrophobic bonds (Gly-88, Leu-86, Met-0, Val-44, Cys-1, Gly-46, and ASP-47). Table 3 provides the detailed information of binding energy and interactions. Molecular docking score of R1-R12 on MAPK10 protein (PDB ID: 3TTJ) was demonstrated in the "Homosapiens" mode. Based on the docking score, the priority of affinity binding energy is as follows: $R 12>R 10>R 9=R 5>R 8>R 3=R 11>R 4=R 6>R 1>R 2>R 7$. The twelve affinity binding energy of R1-MAPK10, R2-MAPK10, R3-MAPK10, R4 -MAPK10, R5-MAPK10, R6-MAPK10, R7-MAPK10, R8MAPK10, R9-MAPK10, R10-MAPK10, R11-MAPK10, and R12-MAPK10 revealed -6.4, -6.1, -6.7, -6.5, -7.1, $-6.5,-7.1,-6.5,-5.6,-6.9,-7.1,-7.4,-6.7$, and $-7.5 \mathrm{kcal} / \mathrm{mol}$, respectively. The rofecoxib (R12) had the strongest affinity on MAPK10. Interaction analysis of best-docked compound namely "Rofecoxib" resulted three hydrogen bonds (Asn-194, Lys-191, Ser-217) and seven hydrophobic bonds (Asp-189, Arg- 
230, Thr-203, Leu-210, Gly-209, Ala-211, Arg-107). Table 4 provides the detailed information of binding energy and interactions. Molecular docking score of B1-B2 on BAD protein (PDB ID: 1G5J) was also analyzed in the "Homo Sapiens" mode. Based on the docking score, the order of priority of binding energy is given: $B 2>B 1$. The two-affinity binding energy of B1-BAD and B2-BAD demonstrated -6.8 and -7.1 $\mathrm{kcal} / \mathrm{mol}$, respectively. The indomethacin (B2) had the strongest affinity on BAD. Interaction analysis of best-docked compound namely "Indomethacin" resulted one hydrogen bond (Asp-180) and eight hydrophobic bonds (Arg-169, Tyr-124, Phe-127, Val-131, Glu-128, His-181, Thr-176, Trp-173). Table 5 provides the detailed information of binding energy and interactions. Figure 10 depicts that the three NSAIDs (6MNA, Rofecoxib, and Indomethacin) might be the potential anti-inflammatory agents against COVID-19

\section{Materials And Methods}

\section{NSAIDs linked to selected genes or COVID-19 related genes}

Based on SMILES, targeted genes of the NSAIDs approved by FDA (U.S. Food \& Drug Administration) were identified utilizing Similarity Ensemble Approach (SEA) (http://sea.bkslab.org/) and Swiss Target Prediction (STP) (http://www.swisstargetprediction.ch/) with the "Homosapience" mode. COVID-19 related genes were identified by browsing PubChem (https://pubchem.ncbi.nlm.nih.gov/). The overlapping genes between NSAIDs targeted genes and COVID-19 related genes were identified and visualized by Venny 2.1 (https://bioinfogp.cnb.csic.es/tools/venny/)

\section{Network construction of interactions between NSAIDs targeted genesand COVID-19related genes}

The overlapping genes interactions between NSAIDs targeted genes and COVID-19 related genes were analyzed by STRING (https://string-db.org/).

\section{Signaling pathway enrichment analysis of overlapping genes}

Genes-genes interaction figure was visualized by STRING (https://string-db.org/). RStudio plotted the bubble chart of KEGG (Kyoto Encyclopedia of Genes and Genomes) pathway enrichment analysis of overlapping genes. Using RStudio, the most significant genes among signaling pathways and correlation of NSAIDs on the most significant genes were analyzed. The results suggest a hint at the unknown molecular mechanism(s) of the most potent NSAIDs against COVID-19.

\section{Binding affinity energy value of the most potent NSAIDs on genes in silico}

The binding affinity energy measurement of the uttermost NSAIDs on key genes was established by Autodock (http://autodock.scripps.edu/), Vina (http://vina.scripps.edu/), Pymol (https://pymol.org/2/).

\section{Discussion}


NSAIDs-genes networking analysis demonstrated that the clinical effect of NSAIDs on COVID-19 was directly related to 26 genes. The results of KEGG pathway enrichment analysis of 26 genes suggested that 26 signaling pathways were associated with the occurrence and development of the COVID-19 symptoms. The correlations of 26 signaling pathways with COVID-19 symptoms were succinctly discussed as follows. PPAR (Peroxisome Proliferator-Activated Receptor) signaling pathway: A report shows that PPARy (Peroxisome Proliferator-Activated Receptor-gamma), PPARa (Peroxisome ProliferatorActivated Receptor-alpha), and PPARß/ס (Peroxisome Proliferator-Activated Receptor-beta/delta) agonists have anti-inflammatory and immunomodulatory functions ${ }^{16}$. MAPK (Mitogen-Activated Protein Kinase) signaling pathway: The mechanisms of p38 MAPK inactivation might be a significant therapy against the SARS infected cells ${ }^{17}$. Additionally, MAPK stimulates cytokine production such as IL-10 (Interleukin 10), TNF- a (Tumor Necrosis Factor-Alpha), IL-4 (Interleukin 4), and IFN- $\mathrm{Y}$ (Interferon gamma) 18. This report shows a coincidence with our suggested strategy in this study. ErbB (Erythroblastic Leukemia Viral Oncogene Homolog) signaling pathway: ErbB signaling reduces the proinflammatory activation in cardiac cells ${ }^{19}$. RAS (Renin Angiotensin System) signaling pathway: Inactivation of RAS can reduce tissue damage in COVID-19 patients. In addition, ACE (Angiotensin Converting Enzyme) antagonists block the response of RAS system ${ }^{20}$. cGMP-PKG (Cyclic GMP-Protein Kinase G) signaling pathway: The activation of CGMP-PKG signaling inhibits inflammatory response in the prostate, and also decreases CCL5 (C-C Motif Chemokine Ligand 5) release in CD8 ${ }^{+} \mathrm{T}$ cells (Cluster of Differentiation $8 \mathrm{~T}$ cells) ${ }^{21}$. cAMP (Cyclic Adenosine Monophosphate) signaling pathway: The elevation of cAMP leads to diverse cellular effects, such as airway smooth muscle relaxation, repressed effects on cellular inflammation, and immune responses ${ }^{22}$. NF-KB (Nuclear Factor kappa-light-chain-enhancer of activated $B$ cells) signaling pathway: Activation of the NF-KB signaling pathway gives rise to the inflammation induced by the SARS-CoV infection. In contrast, NF-KB inhibitors are the potential antivirals against SARS$\mathrm{CoV}$, and can also contribute to other pathogenic human coronaviruses ${ }^{23}$. FOXO (Forkhead box protein 01) signaling pathway: Decrease of FOXO3 (Forkhead box protein 03) in T cells inhibits apoptosis, enhances multifunction of CD8 cells, and elevates viral control ${ }^{24}$. Sphingolipid signaling pathway: Sphingolipids play a vital role to protect lung from damages, and the control of sphingolipid signaling pathways may give a good therapeutic efficacy ${ }^{25}$. Wnt (Wingless/Integrated) signaling pathway: Wnt signaling involves with the prime inflammatory pathways like intestinal inflammation. Also, elucidating the mutual modes of Wnt ligands and cytokines manifest new treatment strategies for chronic colitis and other inflammatory diseases ${ }^{26}$. VEGF (Vascular Endothelial Growth Factor) signaling pathway: A report suggested that VEGFA (Vascular Endothelial Growth Factor A) is inhibited by the activation of ACE2 (Angiotensin-Converting Enzyme 2). However, ACE2 is downregulated by the attack of COVID-19. Subsequently, activation of VEGFA elevates vascular permeability and severity of endothelial damage ${ }^{27}$. TLR (Toll-like receptor) signaling pathway: Toll-like receptors (TLRs) play a pivotal role in the innate immune system and contribute to defend host cells by recognizing PAMPs (Pathogen-Associated Molecular Patterns) induced by various microbes ${ }^{28}$. The activation of TLRs triggers an array of response resulting into expression of different cytokines and chemokines, phagocytosis, and even apoptotic case activation to induce programmed cell death ${ }^{29}$. NOD-like receptor (NLR) signaling pathway: Nod-like 
receptors (NLRs) have been revealed as the major microbial signals that take part in the universal immune responses to infection, and also contribute to the prevention of infections ${ }^{30}$. RIG-Illike receptor (RLR) signaling pathway: RIG--like receptors (RLRs) play a vital role in pathogen sensor of RNA virus infection, which enhances the antiviral immunity by sensing foreign RNA ${ }^{31}$. IL-17 (Interleukin-17) signaling pathway: IL-17 receptor inhibitors are widely used to ameliorate the inflammatory acuteness to date. Furthermore, it is a potential target to suppress severe inflammation induced by COVID-19 ${ }^{32}$. Fc epsilon RI signaling pathway: Fc epsilon RI interconnecting causes mast cell degranulation and synthesis of proinflammatory mediators ${ }^{33}$. TNF (Tumor Necrosis Factor) signaling pathway: TNF deficit is associated with dysfunctional secretion of inflammatory cytokine, leading to lung pathology and death during respiratory poxvirus infection, and thus TNF is very significant element for regulating inflammation 34. Neurotrophin signaling pathway: COVID-19 causes severe brain damage and destruction of central nervous system derived from neurotrophin (Huang and Reichardt 2001). Insulin signaling pathway: Obesity-oriented insulin resistance is associated with the induction of proinflammatory macrophage, leads to inflammation of adipose tissue ${ }^{37}$. $\mathrm{GnRH}$ (Gonadotropin-Releasing Hormone) signaling pathway: Disrupted BBB (Blood Brain Barrier) by viral infection, lymphocytes (B and T cells), monocytes, and granulocytes can penetrate in the brain parenchyma which induce inflammation, resulting in dysregulation of $\mathrm{GnRH}$ neurons. Additionally, the inflammation of $\mathrm{GnRH}$ neurons inhibits $\mathrm{GnRH}$ transport through proinflammatory cytokines by impairing the cytoskeleton ${ }^{38}$. Prolactin signaling pathway: HIV (Human Immunodeficiency Virus) patients have greater prolactin quantity compared to others. Besides, prolactin is regarded as a cytokine to react in immune system ${ }^{39,40}$. Adipocytokine signaling pathway: Adipocytokines stimulate inflammation and disrupting immune response which cause tissue damage. Adipocytokines might also induce proinflammation in RA (Rheumatoid Arthritis) patients and thus lead to the development of bone damage ${ }^{41}$. Oxytocin signaling pathway: Oxytocin interrupts the production of proinflammatory cytokines by inactivating of the elF-2a-ATF4 (Eukaryotic Initiation Factor -2 alphaActivating Transcription Factor 4 ) pathway ${ }^{42}$. Relaxin signaling pathway: Relaxin inhibitors are good therapeutic targets to suppress inflammation caused by airway dysfunction ${ }^{43}$. AGE-RAGE (Advanced Glycation End product -Receptor of Advanced Glycation End product) signaling pathway in diabetic complications: The binding of AGE to its receptor RAGE can trigger the cytokine production, thus, can cause tissue damages, while the blockage of AGE-RAGE can effectively curtail the inflammation ${ }^{44}$. Epithelial cell signaling in Helicobacter pylori infection: Helicobacter pylori interrupts T and B cell signaling to set immune system. It is apparent that COVID-19 patients with Helicobacter pylori might be vulnerable to inflammatory responses ${ }^{45}$.

Generally, SARS-CoV-2 invades in the lungs and throat, induces excessive inflammation, which causes the secretion of cytokines, resulting in severe complications like acute respiratory failure, pneumonia, and acute liver injury (Reyes and Peniche 2019; Nile et al. 2020). Researchers suggested that RAS is a potential route for SARS-CoV-2 induced cellular infection which may be linked to the imbalance of RAS. It was discovered that ACE-2 is the functional receptor for the SARS-CoV-2 to trigger infection in the lung alveolar epithelial cells. The internalization of virus leads to downregulate the ACE-2 on host cell surface 
that could cause the elevation and demotion of the angiotensin-II (All) and angiotensin 1-7 $\left(A_{1-7}\right)$ respectively. Such an imbalance between these angiotensins may induce deleterious effects in the lung and heart. Thus, the SARS-CoV-2 affects humans through this mechanism ${ }^{49-52}$. Therefore, blockade of the RAS may restore the RAS balance by reducing the deleterious effects associated with angiotensin-II 53. Recent evidence showed that RAS inhibitors might be a promising target for relieving acute-severe pneumonia caused by the COVID-19 ${ }^{54}$.

Interestingly, our study identified that the three genes (MAPK 8, MAPK 10, and BAD) are mainly associated with the RAS signaling pathway. MAPK 8 and MAPK 10 are members of the MAPK family which are the key mediators of the inflammation, vasoconstriction, and thrombosis. Besides, overwhelming heart and lung injury in COVID-19 infection might be due to the overactivation of MAPK ${ }^{55}$. Therefore, inactivation of these genes can also be a viable strategy for relieving COVID-19 induced organ injury. In addition, disposal of inflammatory cells by promoting the cell death can be an innovative approach to control excessive inflammation. In this regard, inhibition of the anti-apoptotic Bcl-2 gene can also be a potential target to lessen inflammation ${ }^{56,57}$. Our findings also explored that MAPK8, MAPK10 and BAD genes are related to three, twelve, and two NSAIDs, respectively. During the molecular docking analysis, 6MNA, rofecoxib, and indomethacin revealed promising binding affinity along with highest docking score against MAPK8, MAPK10 and BAD genes, respectively, which indicated that the three (6MNA, Rofecoxib, and Indomethacin) NSAIDs are very potential among all others, may possibly block the RAS signaling pathway by inactivating its associated genes (MAPK8, MAPK10 and BAD), and subsequently suppress SARS-CoV-2 induced cytokine storm.

Among various NSAIDs, indomethacin is a current drug of interest to the clinicians. Primary care physicians (New York) reported that indomethacin had been prescribed to a large number of COVID-19 patients and observed quick recovery from cough, pain, and other symptoms. Such improvements and well-being benefits were not evident in the case of ibuprofen and hydroxychloroquine implementation (Vaduganathan et al. 2020b; Little 2020). Importantly, many researchers previously reported varying degrees of antiviral activity of indomethacin against herpesvirus ${ }^{60}$, pseudorabies virus ${ }^{61}$, cytomegalovirus ${ }^{62}$, hepatitis $B$ virus ${ }^{63}$, vesicular stomatitis virus ${ }^{64}$, rotavirus ${ }^{65}$, and canine coronavirus 11. In contrast, 6MNA (active metabolite of nabumetone) and Rofecoxib are also the potential antiinflammatory drugs, but studies disclosed that they are less potent compared to the indomethacin 66,67 . Hence, such compelling outcomes indicate that indomethacin can be considered to use alone or in combination for antiviral therapy which may assist in combating human coronavirus (SARS-CoV-2).

In summary, NSAIDs-genes network suggested that the therapeutic effect of NSAIDs on COVID-19 was associated with 26 signaling pathways. This study suggests that $6 \mathrm{MNA}$, rofecoxib, and indomethacin are the most potent NSAIDs against COVID-19. The basis of this research is an understanding of how these NSAIDs (which stimulates anti-inflammatory processes against COVID-19) work on COVID-19 patients. That scientific evidence informs the selection of NSAIDs, in turn, provides for clinical design against COVID-19. Our research suggests that the inhibition of BAD-Indomethacin with other two hub genes 
MAPK8-6MNA, MAPK10-Rofecoxib might play cumulative actions by inactivating the RAS signaling pathway against COVID-19. Most recently, efficacy of indomethacin against COVID-19 has been approved clinically. Our study presents that indomethacin is a potent therapeutic candidate to relieve COVID-19 symptoms, which is in line with the many previous studies. However, further clinical trial on indomethacin should be warranted in COVID-19 patients in order to slow down the progression of SARS-CoV-2 and mitigating the severity as well.

\section{Abbreviations}

ACE: Angiotensin-Converting Enzyme;

ACE2: Angiotensin-Converting Enzyme 2;

AGE-RAGE: Advanced Glycation End product /Receptor of Advanced Glycation End product;

BAD: Bcl-2-Associated Death promoter;

BBB: Blood Brain Barrier;

cAMP: Cyclic Adenosine MonoPhosphate;

CCL5 (C-C Motif Chemokine Ligand 5);

$\mathrm{CD}^{+} \mathrm{T}$ cells: Cluster of Differentiation $8 \mathrm{~T}$ cells;

cGMP-PKG: cyclic Guanosine MonoPhosphate - Protein Kinase G;

COVID-19: SARS-CoV-2 virus;

elF-2a-ATF4 (Eukaryotic Initiation Factor -2 alpha- Activating Transcription Factor 4);

ErbB: Erythroblastic Leukemia Viral Oncogene Homolog;

FDA: U.S. Food \& Drug Administration;

FOXO: FOrkhead boX protein 0;

GnRH: Gonadotropin-Releasing Hormone;

HIV: Human Immunodeficiency Virus;

IFN- $ү$ : Interferon gamma;

IL-4: Interleukin 4;

IL-10: Interleukin 10; 
IL-17: Interleukin 17;

KEGG: Kyoto Encyclopedia of Genes and Genomes;

MAPK: Mitogen-Activated Protein Kinase;

MAPK8: Mitogen-Activated Protein Kinase 8;

MAPK10: Mitogen-Activated Protein Kinase 10;

NF- kB: Nuclear Factor Kappa-light-chain-enhancer of activated B cells;

NLR: Nod-Like Receptor;

NLRs: Nod-Like Receptors;

NSAIDs: Non-Steroidal Anti-Inflammatory Drugs;

PPAR: Peroxisome Proliferator-Activated Receptors;

PPARa: Peroxisome Proliferator-Activated Receptor-alpha;

PPARY: Peroxisome Proliferator-Activated Receptor-gamma;

PPARß/ס: Peroxisome Proliferator-Activated Receptor-beta/delta;

PAMPs: Pathogen-Associated Molecular Patterns;

RA: Rheumatoid Arthritis;

RAS: Renin Angiotensin System;

RLR: RIG-I-Like Receptor;

RLRs: RIG-I-Like Receptors;

SARS-CoV-2: Severe Acute Respiratory Syndrome CoronaVirus 2;

SEA: Similarity Ensemble Approach;

STP: Swiss Target Prediction;

TLR: Toll-like receptor;

TLRs: Toll-like receptors;

TNF: Tumor Necrosis Factor; 
TNF-a: Tumor Necrosis Factor-Alpha;

VEGF: Vascular Endothelial Growth Factor;

VEGFA: Vascular Endothelial Growth Factor A;

WHO: World Health Organization;

Wnt: Wingless/Integrated

\section{Declarations}

\section{Data availability}

All data generated or analysed during this study are included in this published article (and its Supplementary Information files).

\section{Acknowledgements}

This research was acknowledged by the Department of Bio-Health Technology, Kangwon National University, Chuncheon 24341, Republic of Korea.

\section{Author contribution}

Ki Kwang Oh and Md. Adnan: Conceptualization, Methodology, Formal analysis, Investigation, Data Curation, Writing - Original Draft. Ki Kwang Oh and Md. Adnan: Software, Investigation, Data Curation. Ki Kwang Oh and Md. Adnan: Validation, Writing - Review \& Editing. Dong Ha Cho: Supervision, Project administration

\section{Competing interests}

The authors declare no competing interests.

\section{References}

1. Harapan, H. et al. Coronavirus disease 2019 (COVID-19): A literature review. J. Infect. Public Health (2020).

2. Pericàs, J. M. et al. COVID-19: From epidemiology to treatment. Eur. Heart J. (2020) doi:10.1093/eurheartj/ehaa462.

3. Astuti, I. \& Ysrafil. Severe Acute Respiratory Syndrome Coronavirus 2 (SARS-CoV-2): An overview of viral structure and host response. Diabetes Metab. Syndr. Clin. Res. Rev.14, 407-412 (2020).

4. Oran, D. P. \& Topol, E. J. Prevalence of Asymptomatic SARS-CoV-2 Infection. Ann. Intern. Med. (2020) doi:10.7326/m20-3012. 
5. Wu, R. et al. An Update on Current Therapeutic Drugs Treating COVID-19. Current Pharmacology Reports vol. 6 56-70 (2020).

6. Ozili, P. COVID-19 in Africa: socio-economic impact, policy response and opportunities. Int. J. Sociol. Soc. Policy (2020) doi:10.1108/IJSSP-05-2020-0171.

7. Capuano, A., Scavone, C., Racagni, G. \& Scaglione, F. NSAIDs in patients with viral infections, including Covid-19: Victims or perpetrators? Pharmacol. Res.157, 104849 (2020).

8. Zhang, W. et al. The use of anti-inflammatory drugs in the treatment of people with severe coronavirus disease 2019 (COVID-19): The experience of clinical immunologists from China. Clin. Immunol. 108393 (2020).

9. Sodhi, M. \& Etminan, M. Safety of Ibuprofen in Patients With COVID-19: Causal or Confounded? Chest vol. 158 55-56 (2020).

10. Meek, I. L., van de Laar, M. A. F. J. \& Vonkeman, H. E. Non-steroidal anti-inflammatory drugs: An overview of cardiovascular risks. Pharmaceuticals vol. 3 2146-2162 (2010).

11. Amici, C. et al. Indomethacin has a potent antiviral activity against SARS coronavirus. Antivir. Ther.11, 1021 (2006).

12. Xu, T., Gao, X., Wu, Z., Selinger, D. W. \& Zhou, Z. Indomethacin has a potent antiviral activity against SARS CoV-2 in vitro and canine coronavirus in vivo. bioRxiv (2020).

13. Russell, B., Moss, C., Rigg, A. \& Van Hemelrijck, M. COVID-19 and treatment with NSAIDs and corticosteroids: should we be limiting their use in the clinical setting? Ecancermedicalscience14, (2020).

14. Oh, K. K., Adnan, M. \& Cho, D. H. Network pharmacology approach to bioactive chemical compounds identified from Lespedeza bicolor lignum methanol extract by GC-MS for amelioration of hepatitis. Gene Reports 100851 (2020).

15. Tang, J. \& Aittokallio, T. Network Pharmacology Strategies Toward Multi-Target Anticancer Therapies: From Computational Models to Experimental Design Principles. Curr. Pharm. Des.20, 2336 (2014).

16. Belvisi, M. G. \& Mitchell, J. A. Targeting PPAR receptors in the airway for the treatment of inflammatory lung disease. British Journal of Pharmacology vol. 158 994-1003 (2009).

17. Mizutani, T., Fukushi, S., Saijo, M., Kurane, I. \& Morikawa, S. Phosphorylation of p38 MAPK and its downstream targets in SARS coronavirus-infected cells. Biochem. Biophys. Res. Commun.319, 1228-1234 (2004).

18. De Souza, A. P. et al. MAPK involvement in cytokine production in response to Corynebacterium pseudotuberculosis infection. BMC Microbiol.14, (2014).

19. Ryzhov, S. et al. ERBB signaling attenuates proinflammatory activation of nonclassical monocytes. Am. J. Physiol. Circ. Physiol.312, H907-H918 (2017).

20. Aleksova, A. et al. COVID-19 and renin-angiotensin system inhibition: role of angiotensin converting enzyme 2 (ACE2) - Is there any scientific evidence for controversy? Journal of Internal Medicine 
(2020) doi:10.1111/joim.13101.

21. Jin, S. et al. Activation of cGMP/PKG/p65 signaling associated with PDE5-Is downregulates CCL5 secretion by $\mathrm{CD} 8{ }^{+} \mathrm{T}$ cells in benign prostatic hyperplasia. Prostate79, 909-919 (2019).

22. Yan, K., Gao, L. N., Cui, Y. L., Zhang, Y. \& Zhou, X. The cyclic AMP signaling pathway: Exploring targets for successful drug discovery (review). Mol. Med. Rep.13, 3715-3723 (2016).

23. DeDiego, M. L. et al. Inhibition of NF-B-Mediated Inflammation in Severe Acute Respiratory Syndrome Coronavirus-Infected Mice Increases Survival. J. Virol.88, 913-924 (2014).

24. Sullivan, J. A., Kim, E. H., Plisch, E. H. \& Suresh, M. FOXO3 Regulates the CD8 T Cell Response to a Chronic Viral Infection. J. Virol.86, 9025-9034 (2012).

25. Abu-Farha, M. et al. The role of lipid metabolism in COVID-19 virus infection and as a drug target. International Journal of Molecular Sciences vol. 21 (2020).

26. Moparthi, L. \& Koch, S. Wnt signaling in intestinal inflammation. Differentiation vol. 108 24-32 (2019).

27. Turkia, M. COVID-19 As An Endothelial Disease and Its Relationship to Vascular Endothelial Growth Factor (VEGF) and lodide. SSRN Electron. J. (2020) doi:10.2139/ssrn.3604987.

28. Kawasaki, T. \& Kawai, T. Toll-like receptor signaling pathways. Frontiers in Immunology vol. 5 (2014).

29. Ashayeri Ahmadabad, R., Khaleghi Ghadiri, M. \& Gorji, A. The role of Toll-like receptor signaling pathways in cerebrovascular disorders: The impact of spreading depolarization. Journal of Neuroinflammation vol. 17 1-13 (2020).

30. Carneiro, L. A. M., Travassos, L. H. \& Girardin, S. E. Nod-like receptors in innate immunity and inflammatory diseases. Annals of Medicine vol. 39 581-593 (2007).

31. Chan, Y. K. \& Gack, M. U. RIG--llike receptor regulation in virus infection and immunity. Current Opinion in Virology vol. 12 7-14 (2015).

32. Pacha, O., Sallman, M. A. \& Evans, S. E. COVID-19: a case for inhibiting IL-17? Nature Reviews Immunology vol. 20 345-346 (2020).

33. Klemm, S. \& Ruland, J. Inflammatory signal transduction from the FcERI to NF-kB. Immunobiology vol. $211815-820$ (2006).

34. Junaliah Tuazon Kels, M. et al. TNF deficiency dysregulates inflammatory cytokine production leading to lung pathology and death during respiratory poxvirus infection. bioRxiv 2019.12.22.883728 (2019) doi:10.1101/2019.12.22.883728.

35. COVID-19: Severe brain damage possible even with mild symptoms | Sciencel In-depth reporting on science and technology | DW | 09.07.2020. https://www.dw.com/en/coronavirus-brain-damage/a54111054.

36. Huang, E. J. \& Reichardt, L. F. Neurotrophins: Roles in neuronal development and function. Annual Review of Neuroscience vol. 24 677-736 (2001).

37. Shimobayashi, M. et al. Insulin resistance causes inflammation in adipose tissue. J. Clin. Invest.128, 1538-1550 (2018). 
38. Barabás, K., Szabó-Meleg, E. \& Ábrahám, I. M. Effect of inflammation on female gonadotropinreleasing hormone $(\mathrm{GnRH})$ neurons: Mechanisms and consequences. International Journal of Molecular Sciences vol. 21 (2020).

39. Acharya, S., Fernando, R. \& Gama, R. Case Report Gynaecomastia, hyperprolactinaemia and HIV infection.

40. Borba, V. V., Zandman-Goddard, G. \& Shoenfeld, Y. Prolactin and autoimmunity: The hormone as an inflammatory cytokine. Best Practice and Research: Clinical Endocrinology and Metabolism vol. 33 101324 (2019).

41. Ruscitti, P. et al. Adipocytokines in rheumatoid arthritis: The hidden link between inflammation and cardiometabolic comorbidities. Journal of Immunology Research vol. 2018 (2018).

42. Inoue, T. et al. Oxytocin Suppresses Inflammatory Responses Induced by Lipopolysaccharide through Inhibition of the elF-2a-ATF4 Pathway in Mouse Microglia. Cells (2019) doi:10.3390/cells8060527.

43. Martin, B. et al. Relaxin reverses inflammatory and immune signals in aged hearts. PLoS One (2018) doi:10.1371/journal.pone.0190935.

44. Ramasamy, R., Yan, S. F. \& Schmidt, A. M. Receptor for AGE (RAGE): Signaling mechanisms in the pathogenesis of diabetes and its complications. Ann. N. Y. Acad. Sci.1243, 88-102 (2011).

45. Reyes, V. E. \& Peniche, A. G. Helicobacter pylori deregulates $T$ and $B$ cell signaling to trigger immune evasion. in Current Topics in Microbiology and Immunology vol. 421 229-265 (Springer Verlag, 2019).

46. Coronavirus: What Happens To People's Body If They Get Infected. https://www.webmd.com/lung/coronavirus-covid-19-affects-body\#2.

47. Nile, S. H. et al. COVID-19: Pathogenesis, cytokine storm and therapeutic potential of interferons. Cytokine and Growth Factor Reviews vol. 53 66-70 (2020).

48. What Are the Complications of Coronavirus (COVID-19)? https://www.webmd.com/lung/coronaviruscomplications\#1.

49. Vaduganathan, M. et al. Renin-angiotensin-aldosterone system inhibitors in patients with Covid-19. N. Engl. J. Med.382, 1653-1659 (2020).

50. Sama, I. E. et al. Circulating plasma concentrations of angiotensin-converting enzyme 2 in men and women with heart failure and effects of renin-angiotensin-aldosterone inhibitors. Eur. Heart J.41, 1810-1817 (2020).

51. Bloch, M. J. Renin-Angiotensin System Blockade in COVID-19: Good, Bad, or Indifferent?*. J. Am. Coll. Cardiol.76, 277 (2020).

52. Mascolo, A. et al. Renin-angiotensin system and Coronavirus disease 2019: A narrative review. Front. Cardiovasc. Med.7, (2020).

53. Xu, X. et al. Effective treatment of severe COVID-19 patients with tocilizumab. Proc. Natl. Acad. Sci. U. S. A.117, 10970-10975 (2020). 
54. Sun, M. L., Yang, J. M., Sun, Y. P. \& Su, G. H. [Inhibitors of RAS Might Be a Good Choice for the Therapy of COVID-19 Pneumonia]. Zhonghua Jie He He Hu Xi Za Zhi43, 219-222 (2020).

55. Grimes, J. M. \& Grimes, K. V. p38 MAPK inhibition: A promising therapeutic approach for COVID-19. J. Mol. Cell. Cardiol.144, 63-65 (2020).

56. Bulanova, D. et al. Antiviral properties of chemical inhibitors of cellular anti-apoptotic Bcl-2 proteins. Viruses9, 271 (2017).

57. Tian, B. et al. Bcl-2 inhibitors reduce steroid-insensitive airway inflammation. J. Allergy Clin. Immunol.140, 418-430 (2017).

58. Repurposing indomethacin for COVID-19 - Hospital Healthcare EuropeHospital Healthcare Europe. https://hospitalhealthcare.com/covid-19/repurposing-indomethacin-for-covid-19/.

59. Little, P. Non-steroidal anti-inflammatory drugs and covid-19. The BMJ vol. 368 (2020).

60. Reynolds, A. E. \& Enquist, L. W. Biological interactions between herpesviruses and cyclooxygenase enzymes. Rev. Med. Virol.16, 393-403 (2006).

61. Ray, N., Bisher, M. E. \& Enquist, L. W. Cyclooxygenase-1 and-2 are required for production of infectious pseudorabies virus. J. Virol.78, 12964-12974 (2004).

62. Schröer, J. \& Shenk, T. Inhibition of cyclooxygenase activity blocks cell-to-cell spread of human cytomegalovirus. Proc. Natl. Acad. Sci.105, 19468-19473 (2008).

63. Bahrami, H. et al. Effects of indomethacin on viral replication markers in asymptomatic carriers of hepatitis B: a randomized, placebo-controlled trial. Am. J. Gastroenterol.100, 856-861 (2005).

64. Chen, N., Warner, J. L. \& Reiss, C. S. NSAID treatment suppresses VSV propagation in mouse CNS. Virology276, 44-51 (2000).

65. Rossen, J. W. A., Bouma, J., Raatgeep, R. H. C., Büller, H. A. \& Einerhand, A. W. C. Inhibition of cyclooxygenase activity reduces rotavirus infection at a postbinding step. J. Virol.78, 9721-9730 (2004).

66. Melarange, R. et al. Anti-inflammatory and gastrointestinal effects of nabumetone or its active metabolite, 6MNA (6-methoxy-2-naphthylacetic acid): comparison with indomethacin. Agents Actions36, C82-C83 (1992).

67. Van Der Heide, H. J. L., Rijnberg, W. J., Van Sorge, A., Van Kampen, A. \& Schreurs, B. W. Similar effects of rofecoxib and indomethacin on the incidence of heterotopic ossification after hip arthroplasty. Acta Orthop.78, 90-94 (2007).

\section{Supporting Information}

\section{Supplementary Table S1}

(PDF)

\section{Supplementary Table S2}


(PDF)

Supplementary Table S3

(PDF)

Supplementary Table S4

(PDF)

Supplementary Figure S1

(PDF)

\section{Tables}

Table 1. A list of 20 NSAIDs approved by FDA 


\begin{tabular}{|c|c|c|c|}
\hline No. & Drug name & PubChem CID & Mechanism of action \\
\hline 1 & Flubiprofen & 3394 & Nonselective COX inhibitor \\
\hline 2 & Ibuprofen & 3672 & Nonselective COX inhibitor \\
\hline 3 & Indomethacin & 3715 & Nonselective COX inhibitor \\
\hline 4 & Ketorolac & 3826 & Nonselective COX inhibitor \\
\hline 5 & Mefenamic acid & 4044 & Nonselective COX inhibitor \\
\hline 6 & Piroxicam & 54676228 & Nonselective COX inhibitor \\
\hline 7 & Diflunisal & 3059 & Prostaglandin synthesis inhibitor \\
\hline 8 & Fenoprofen & 3342 & Prostaglandin synthesis inhibitor \\
\hline 9 & Naproxen & 156391 & Prostaglandin synthesis inhibitor \\
\hline 10 & Sulindac & 1548887 & Prostaglandin synthesis inhibitor \\
\hline 11 & Tolmetin & 5509 & Prostaglandin synthesis inhibitor \\
\hline 12 & Ketoprofen & 3825 & Selective COX-1 inhibitor \\
\hline 13 & Oxaprozin & 4614 & Selective COX-1 inhibitor \\
\hline 14 & Celecoxib & 2662 & Selective COX-2 inhibitor \\
\hline 15 & Rofecoxib & 5090 & Selective COX-2 inhibitor \\
\hline 16 & Valdecoxib & 119607 & Selective COX-2 inhibitor \\
\hline 17 & Diclofenac & 3033 & Selective COX-2 inhibitor \\
\hline 18 & Etodolac & 3308 & Selective COX-2 inhibitor \\
\hline 19 & Meloxicam & 54677470 & Selective COX-2 inhibitor \\
\hline $20 *$ & 6MNA & 32176 & Selective COX-2 inhibitor \\
\hline
\end{tabular}

* 6MNA (Active form) of Nabumetone (Prodrug)

Table 2. Target genes in 26 signaling pathways enrichment related to COVID-19. 


\begin{tabular}{|c|c|c|c|}
\hline $\begin{array}{l}\text { KEGG ID \& } \\
\text { Description }\end{array}$ & Target genes & RichFactor & $\begin{array}{l}\text { False } \\
\text { discovery } \\
\text { rate }\end{array}$ \\
\hline $\begin{array}{l}\text { hsa04014: Ras } \\
\text { signaling } \\
\text { pathway }\end{array}$ & MAPK8,MAPK10,BAD & 0.013157895 & 0.0071 \\
\hline $\begin{array}{l}\text { hsa04921: } \\
\text { Oxytocin } \\
\text { signaling } \\
\text { pathway }\end{array}$ & PTGS2,PPP1CA & 0.013422819 & 0.0294 \\
\hline $\begin{array}{l}\text { hsa04010: } \\
\text { MAPK signaling } \\
\text { pathway }\end{array}$ & MAPK8,MAPK10,MAPK14,CASP3 & 0.013651877 & 0.0016 \\
\hline $\begin{array}{l}\text { hsa04310: Wnt } \\
\text { signaling } \\
\text { pathway }\end{array}$ & MAPK8,MAPK10 & 0.013986014 & 0.0276 \\
\hline $\begin{array}{l}\text { hsa04022: } \\
\text { cGMP -PKG } \\
\text { signaling } \\
\text { pathway }\end{array}$ & ENDRA,BAD,PPP1CA & 0.01875 & 0.003 \\
\hline $\begin{array}{l}\text { hsa04064: NF- } \\
\text { kappa B } \\
\text { signaling } \\
\text { pathway }\end{array}$ & CXCL8,PTGS2 & 0.021505376 & 0.0136 \\
\hline $\begin{array}{l}\text { hsa04926: } \\
\text { Relaxin } \\
\text { signaling } \\
\text { pathway }\end{array}$ & MAPK8,MAPK10,MAPK14 & 0.023076923 & 0.0018 \\
\hline $\begin{array}{l}\text { hsa04068: FoxO } \\
\text { signaling } \\
\text { pathway }\end{array}$ & MAPK8,MAPK10,MAPK14 & 0.023076923 & 0.0018 \\
\hline $\begin{array}{l}\text { hsa04071: } \\
\text { Sphingolipid } \\
\text { signaling } \\
\text { pathway }\end{array}$ & MAPK8,MAPK10,MAPK14 & 0.025862069 & 0.0014 \\
\hline $\begin{array}{l}\text { hsa04910: } \\
\text { Insulin signaling } \\
\text { pathway }\end{array}$ & MAPK8,MAPK10,BAD,PPP1CA & 0.029850746 & 0.00013 \\
\hline $\begin{array}{l}\text { hsa04621: NOD- } \\
\text { like receptor } \\
\text { signaling } \\
\text { pathway }\end{array}$ & MAPK8,MAPK10,MAPK14,CXCL8,CASP1 & 0.030120482 & 0.0000197 \\
\hline $\begin{array}{l}\text { hsa04024: } \\
\text { cAMP signaling } \\
\text { pathway }\end{array}$ & ENDRA,MAPK8,BAD,MAPK10,PPP1CA,PPARA & 0.030769231 & 0.00000373 \\
\hline hsa04912: & MAPK8,MAPK10,MAPK14 & 0.034090909 & 0.00072 \\
\hline
\end{tabular}


GnRH signaling

pathway

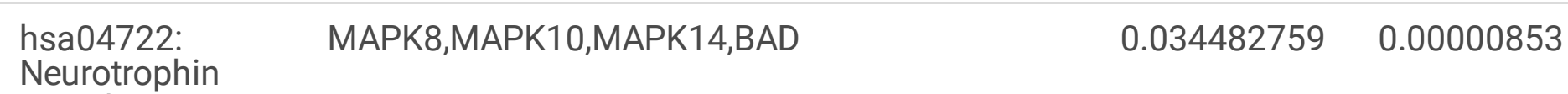

signaling

pathway

hsa04012: ErbB MAPK8,MAPK10,BAD $\quad 0.036144578 \quad 0.00062$

signaling

pathway

hsa04620: Toll- $\quad$ MAPK8,MAPK10,MAPK14,CXCL8 $\quad 0.039215686 \quad 0.0000581$

like receptor

signaling

pathway

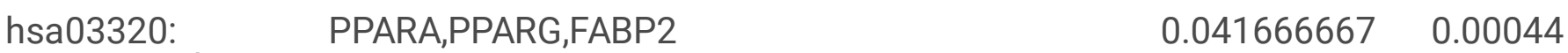

PPAR signaling

pathway

hsa04920:

MAPK8,MAPK10,PPARA

$0.043478261 \quad 0.00041$

Adipocytokine

signaling

pathway

$\begin{array}{llll}\text { hsa04917: } & \text { MAPK8,MAPK10,MAPK14 } & 0.043478261 & 0.00041\end{array}$

Prolactin

signaling

pathway

hsa04664: Fc $\quad$ MAPK8,MAPK10,MAPK14 $\quad 0.044776119 \quad 0.00039$

epsilon RI

signaling

pathway

hsa04668: TNF MAPK8,MAPK10,MAPK14,CASP3,PTGS2 $\quad 0.046296296 \quad 0.00000413$

signaling

pathway

hsa04370:

MAPK8,MAPK10,BAD

$0.050847458 \quad 0.00029$

VEGF signaling

pathway

hsa04933: AGE- MAPK8,MAPK10,MAPK14,CXCL8,CASP1 $\quad 0.051020408 \quad 0.00000373$

RAGE signaling

pathway in

diabetic

complications

hsa04622: RIG-I- MAPK8,MAPK10,MAPK14,CXCL8 $\quad 0.0571428570 .0000197$

like receptor

signaling

pathway

hsa04657: IL-17 MAPK8,MAPK10,MAPK14,CXCL8,CASP3,PTGS2 0.0652173910 .000000135

signaling

pathway 
Table 3. Binding energy and interactions of potential three NSAIDs on MAPK8 (PDB ID:4YR8) 


\begin{tabular}{|c|c|c|c|c|c|c|}
\hline & & & & & $\begin{array}{l}\text { Hydrogen } \\
\text { Bond } \\
\text { Interactions }\end{array}$ & $\begin{array}{l}\text { Hydrophobic } \\
\text { Interactions }\end{array}$ \\
\hline Protein & Ligand & $\begin{array}{l}\text { PubChem } \\
\text { ID }\end{array}$ & Symbol & $\begin{array}{l}\text { Binding } \\
\text { energy }(\mathrm{kcal} / \mathrm{mol})\end{array}$ & $\begin{array}{l}\text { Amino Acid } \\
\text { Residue }\end{array}$ & $\begin{array}{l}\text { Amino Acid } \\
\text { Residue }\end{array}$ \\
\hline \multirow[t]{14}{*}{ 4YR8 } & 6MNA & 32176 & M1 & -7.1 & Lys-218 & $\begin{array}{l}\text { Pro-221, Gly- } \\
199\end{array}$ \\
\hline & & & & & & $\begin{array}{l}\text { Pro-254, } \\
\text { Phe215 }\end{array}$ \\
\hline & & & & & & $\begin{array}{l}\text { Cys-216, Gln- } \\
253\end{array}$ \\
\hline & & & & & & $\begin{array}{l}\text { Pro-210, Lys- } \\
218\end{array}$ \\
\hline & & & & & & $\begin{array}{l}\text { Glu-217, Lys- } \\
225\end{array}$ \\
\hline & $\begin{array}{l}\text { Mefenamic } \\
\text { acid }\end{array}$ & 4044 & M2 & -6.4 & Glu-217 & $\begin{array}{l}\text { Trp-222, Val- } \\
211\end{array}$ \\
\hline & & & & & & $\begin{array}{l}\text { Arg-208, Cys- } \\
216\end{array}$ \\
\hline & & & & & & $\begin{array}{l}\text { Asn-193, Lys- } \\
218\end{array}$ \\
\hline & & & & & & Pro-211 \\
\hline & Etodolac & 3308 & M3 & -6.3 & $\mathrm{n} / \mathrm{a}$ & $\begin{array}{l}\text { Tyr-202, Lys- } \\
203\end{array}$ \\
\hline & & & & & & $\begin{array}{l}\text { Met-200, Gly- } \\
201\end{array}$ \\
\hline & & & & & & $\begin{array}{l}\text { Pro-221, Lys- } \\
218\end{array}$ \\
\hline & & & & & & $\begin{array}{l}\text { Lys-251, Ser- } \\
307\end{array}$ \\
\hline & & & & & & Ala-306 \\
\hline
\end{tabular}

Table 4. Binding energy and interactions of potential twelve NSAIDs on MAPK10 (PDB ID: 3TTJ) 


\begin{tabular}{|c|c|c|c|c|c|c|}
\hline & & & & & $\begin{array}{l}\text { Hydrogen } \\
\text { Bond } \\
\text { Interactions }\end{array}$ & $\begin{array}{l}\text { Hydrophobic } \\
\text { Interactions }\end{array}$ \\
\hline Protein & Ligand & $\begin{array}{l}\text { PubChem } \\
\text { ID }\end{array}$ & Symbol & $\begin{array}{l}\text { Binding } \\
\text { energy }(\mathrm{kcal} / \mathrm{mol})\end{array}$ & $\begin{array}{l}\text { Amino Acid } \\
\text { Residue }\end{array}$ & $\begin{array}{l}\text { Amino Acid } \\
\text { Residue }\end{array}$ \\
\hline \multirow[t]{14}{*}{ 3TTJ } & $\begin{array}{l}\text { Mefenamic } \\
\text { acid }\end{array}$ & 32176 & $\mathrm{R} 1$ & -6.4 & Arg-107 & $\begin{array}{l}\text { Asp-207, Gln- } \\
75\end{array}$ \\
\hline & & & & & & $\begin{array}{l}\text { Leu-206, Lys- } \\
93\end{array}$ \\
\hline & & & & & & $\begin{array}{l}\text { Asn-194, } \\
\text { Asp-207 }\end{array}$ \\
\hline & Naproxen & 4044 & $\mathrm{R} 2$ & -6.1 & $\begin{array}{l}\text { Asn-194, Lys- } \\
93\end{array}$ & $\begin{array}{l}\text { Arg-107, Asp- } \\
189\end{array}$ \\
\hline & & & & & & $\begin{array}{l}\text { Val-225, Lys- } \\
191\end{array}$ \\
\hline & & & & & & $\begin{array}{l}\text { Gln-75, Gly- } \\
73\end{array}$ \\
\hline & Tolmetin & 3308 & R3 & -6.7 & $\begin{array}{l}\text { Asn-194, Asp- } \\
189\end{array}$ & $\begin{array}{l}\text { Lys-106, Leu- } \\
210\end{array}$ \\
\hline & & & & & & $\begin{array}{l}\text { Ala-211, Arg- } \\
110\end{array}$ \\
\hline & & & & & & $\begin{array}{l}\text { Arg-230, Lys- } \\
191\end{array}$ \\
\hline & & & & & & $\begin{array}{l}\text { Arg-107, Thr- } \\
103\end{array}$ \\
\hline & Fenoprofen & 3342 & R4 & -6.5 & $\begin{array}{l}\text { Lys-93, Lys- } \\
191\end{array}$ & $\begin{array}{l}\text { Ser-193, Ser- } \\
72\end{array}$ \\
\hline & & & & & Asn-194 & $\begin{array}{l}\text { Val-78, Gly- } \\
73\end{array}$ \\
\hline & & & & & & $\begin{array}{l}\text { Gln-75, Ala- } \\
74\end{array}$ \\
\hline & & & & & & Arg-107 \\
\hline
\end{tabular}




\begin{tabular}{|c|c|c|c|c|c|}
\hline Ketorolac & 3826 & R5 & -7.1 & $\begin{array}{l}\text { Glu-111, Arg- } \\
107\end{array}$ & $\begin{array}{l}\text { Asp-207, } \\
\text { Leu-206 }\end{array}$ \\
\hline & & & & $\begin{array}{l}\text { Asn-194, Lys- } \\
93\end{array}$ & $\begin{array}{l}\text { Gln-75, Ser- } \\
193\end{array}$ \\
\hline & & & & & $\begin{array}{l}\text { Ser-72, Val- } \\
78\end{array}$ \\
\hline & & & & & Gly-73 \\
\hline \multirow[t]{3}{*}{ Ketoprofen } & 3825 & R6 & -6.5 & $\begin{array}{l}\text { Lys-93, Asn- } \\
194\end{array}$ & $\begin{array}{l}\text { Val-78, Leu- } \\
206\end{array}$ \\
\hline & & & & Ser-193 & $\begin{array}{l}\text { Arg-107, Gln- } \\
75\end{array}$ \\
\hline & & & & & Gly-73 \\
\hline \multirow[t]{3}{*}{ Ibuprofen } & 3672 & R7 & -5.6 & $\begin{array}{l}\text { Lys-93, Ser- } \\
193\end{array}$ & $\begin{array}{l}\text { Leu-206, Ala- } \\
74\end{array}$ \\
\hline & & & & Asn-194 & $\begin{array}{l}\text { Gly-73, Gln- } \\
75\end{array}$ \\
\hline & & & & & Val-78 \\
\hline \multirow[t]{3}{*}{ Flubiprofen } & 3394 & R8 & -6.9 & $\begin{array}{l}\text { Lys-191, Asp- } \\
189\end{array}$ & $\begin{array}{l}\text { Lys-93, Val- } \\
78\end{array}$ \\
\hline & & & & Asn-194 & $\begin{array}{l}\text { Gly-73, Arg- } \\
107\end{array}$ \\
\hline & & & & & Gln-75 \\
\hline \multirow[t]{3}{*}{ Oxaprozin } & 4614 & R9 & -7.1 & $\begin{array}{l}\text { Asn-194, Arg- } \\
107\end{array}$ & $\begin{array}{l}\text { Asp-189, Thr- } \\
103\end{array}$ \\
\hline & & & & Lys-191 & $\begin{array}{l}\text { Ser-217, Val- } \\
225\end{array}$ \\
\hline & & & & & Arg-230 \\
\hline \multirow[t]{2}{*}{ Sulindac } & 1548887 & R10 & -7.4 & Asn-152 & $\begin{array}{l}\text { Arg-107, Asn- } \\
194\end{array}$ \\
\hline & & & & & $\begin{array}{l}\text { Lys-93, Ser- } \\
72\end{array}$ \\
\hline
\end{tabular}


Gly-73, Ser-

193

Ala-74

\begin{tabular}{|c|c|c|c|c|c|}
\hline \multirow[t]{5}{*}{ Diclofenac } & 3033 & R11 & -6.7 & Asn-194 & $\begin{array}{l}\text { Ser-72, Gly- } \\
73\end{array}$ \\
\hline & & & & & $\begin{array}{l}\text { Ser-193, Gln- } \\
75\end{array}$ \\
\hline & & & & & $\begin{array}{l}\text { Arg-107, Lys- } \\
93\end{array}$ \\
\hline & & & & & $\begin{array}{l}\text { Leu-206, Val- } \\
78\end{array}$ \\
\hline & & & & & Gly-71 \\
\hline \multirow[t]{3}{*}{ Rofecoxib } & 5090 & $\mathrm{R} 12$ & -7.5 & $\begin{array}{l}\text { Asn-194, Lys- } \\
191\end{array}$ & $\begin{array}{l}\text { Asp-189, Arg- } \\
230\end{array}$ \\
\hline & & & & Ser-217 & $\begin{array}{l}\text { Thr-203, Leu- } \\
210\end{array}$ \\
\hline & & & & & $\begin{array}{l}\text { Gly-209, Ala- } \\
211\end{array}$ \\
\hline
\end{tabular}

Table 5. Binding energy and interactions of potential two NSAIDs on BAD (PDB ID: 1G5J) 


\begin{tabular}{|c|c|c|c|c|c|c|}
\hline & & & & & $\begin{array}{l}\text { Hydrogen } \\
\text { Bond } \\
\text { Interactions }\end{array}$ & $\begin{array}{l}\text { Hydrophobic } \\
\text { Interactions }\end{array}$ \\
\hline Protein & Ligand & $\begin{array}{l}\text { PubChem } \\
\text { ID }\end{array}$ & Symbol & $\begin{array}{l}\text { Binding } \\
\text { energy }(\mathrm{kcal} / \mathrm{mol})\end{array}$ & $\begin{array}{l}\text { Amino Acid } \\
\text { Residue }\end{array}$ & $\begin{array}{l}\text { Amino Acid } \\
\text { Residue }\end{array}$ \\
\hline \multirow[t]{7}{*}{$1 \mathrm{G} 5 \mathrm{~J}$} & 6MNA & 32176 & B1 & -6.8 & $\begin{array}{l}\text { Trp-173, His- } \\
181\end{array}$ & $\begin{array}{l}\text { Arg-169, Tyr- } \\
124\end{array}$ \\
\hline & & & & & & $\begin{array}{l}\text { Phe-127, } \\
\text { Tyr-177 }\end{array}$ \\
\hline & & & & & & Thr-176 \\
\hline & Indomethacin & 3715 & B2 & -7.1 & Asp-180 & $\begin{array}{l}\text { Arg-169, Tyr- } \\
124\end{array}$ \\
\hline & & & & & & $\begin{array}{l}\text { Phe-127, } \\
\text { Val-131 }\end{array}$ \\
\hline & & & & & & $\begin{array}{l}\text { Glu-128, His- } \\
181\end{array}$ \\
\hline & & & & & & $\begin{array}{l}\text { Thr-176, Trp- } \\
173\end{array}$ \\
\hline
\end{tabular}

Figures 


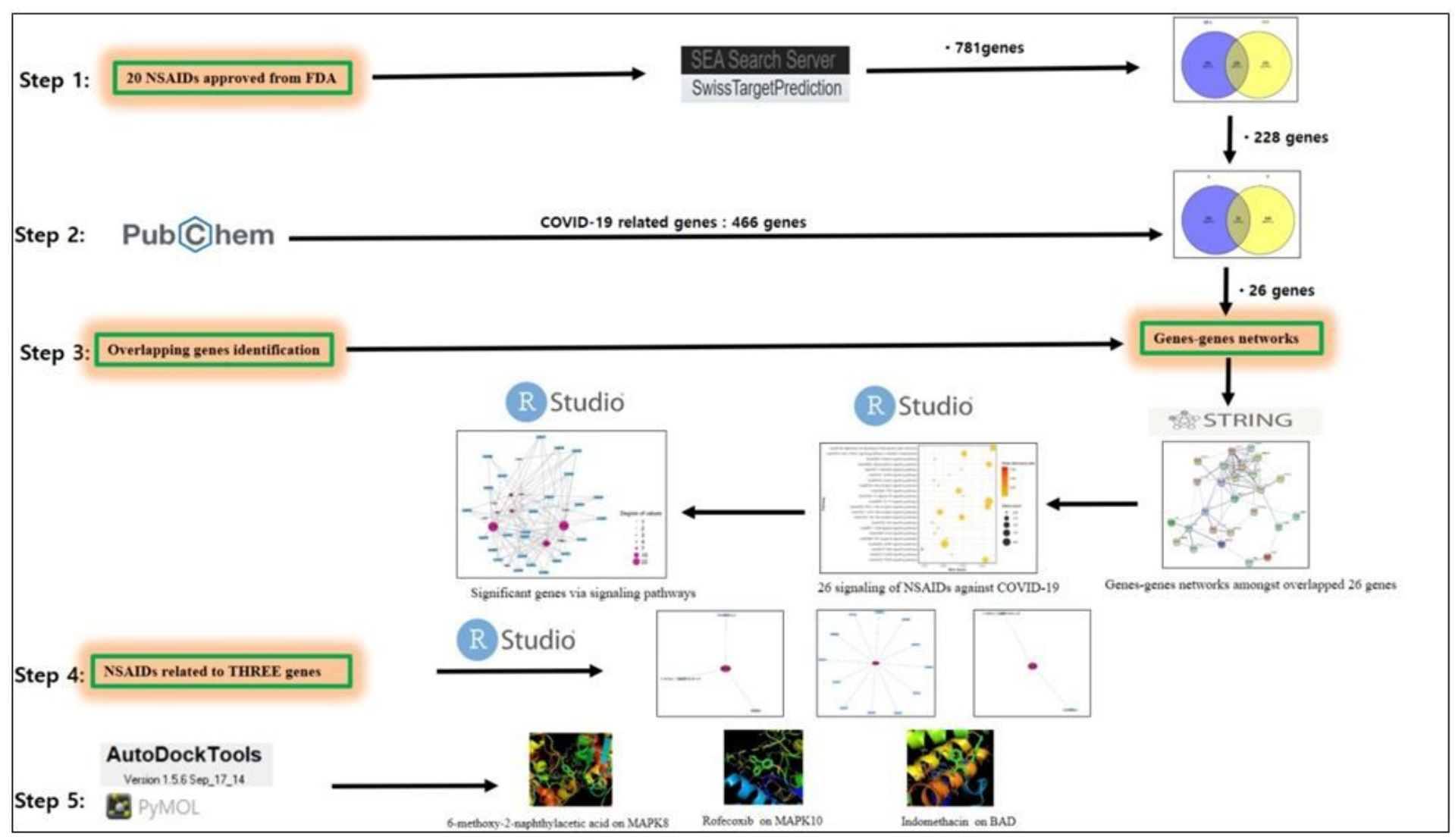

Figure 1

Workflow of network pharmacology analysis of NSAIDs against COVID-19.

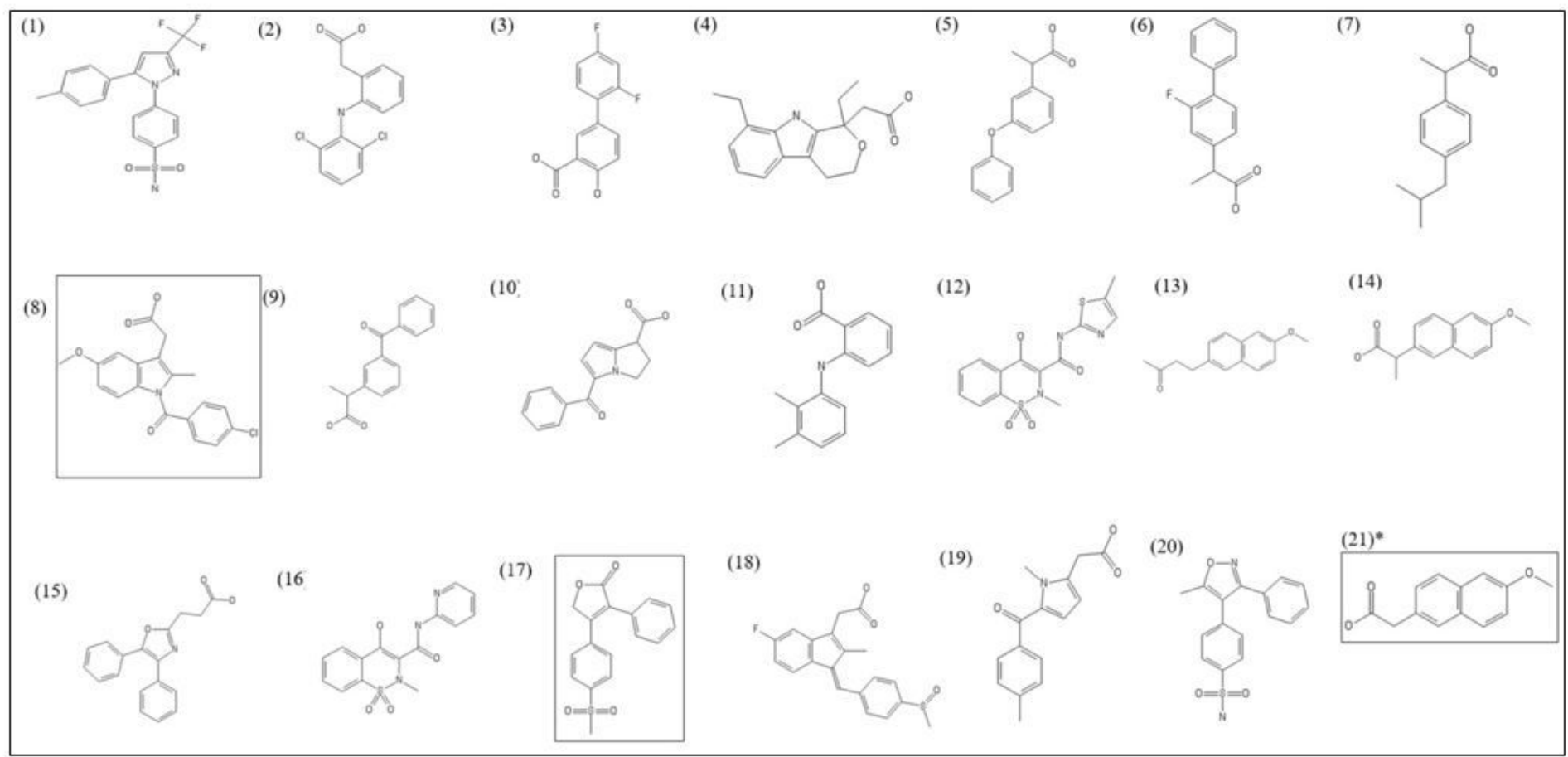

Figure 2 
Structure of 20 NSAIDs and 1 prodrug (1) Celecoxib (2) Diclofenac (3) Diflunisal (4) Etodolac (5) Fenoprofen (6) Flubiprofen (7) Ibuprofen (8) Indomethacin (9) Ketoprofen (10) Ketorolac (11) Mefenamic acid (12) Meloxicam (13) Nabumetone (14) Naproxen (15) Oxaprozin (16) Piroxicam (17) Rofecoxib (18) Sulindac (19) Tolmetin (20) Valdecoxib The three NSAIDs in box line are the most potent NSAIDs candidates against COVID-19*(21): Active form of (13) Nabumeton (Prodrug)

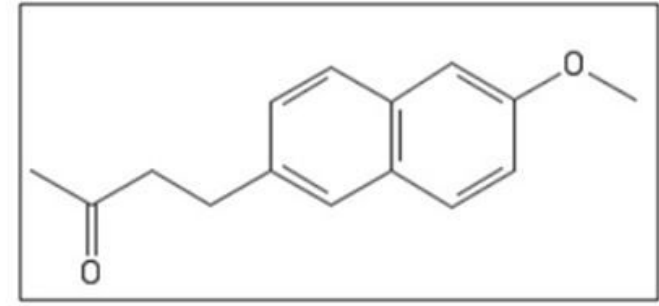

Nabumetone (Prodrug)
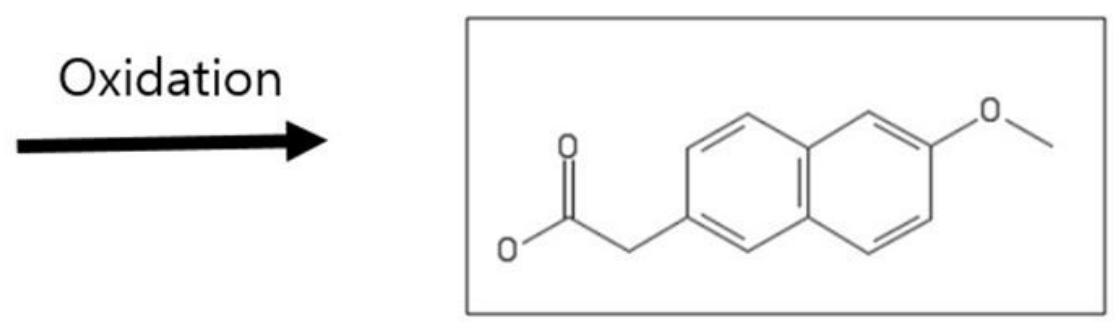

6MNA (Active form)

\section{Figure 3}

An active metabolite (6MNA) of Nabumetone (Prodrug).

\section{SEA}
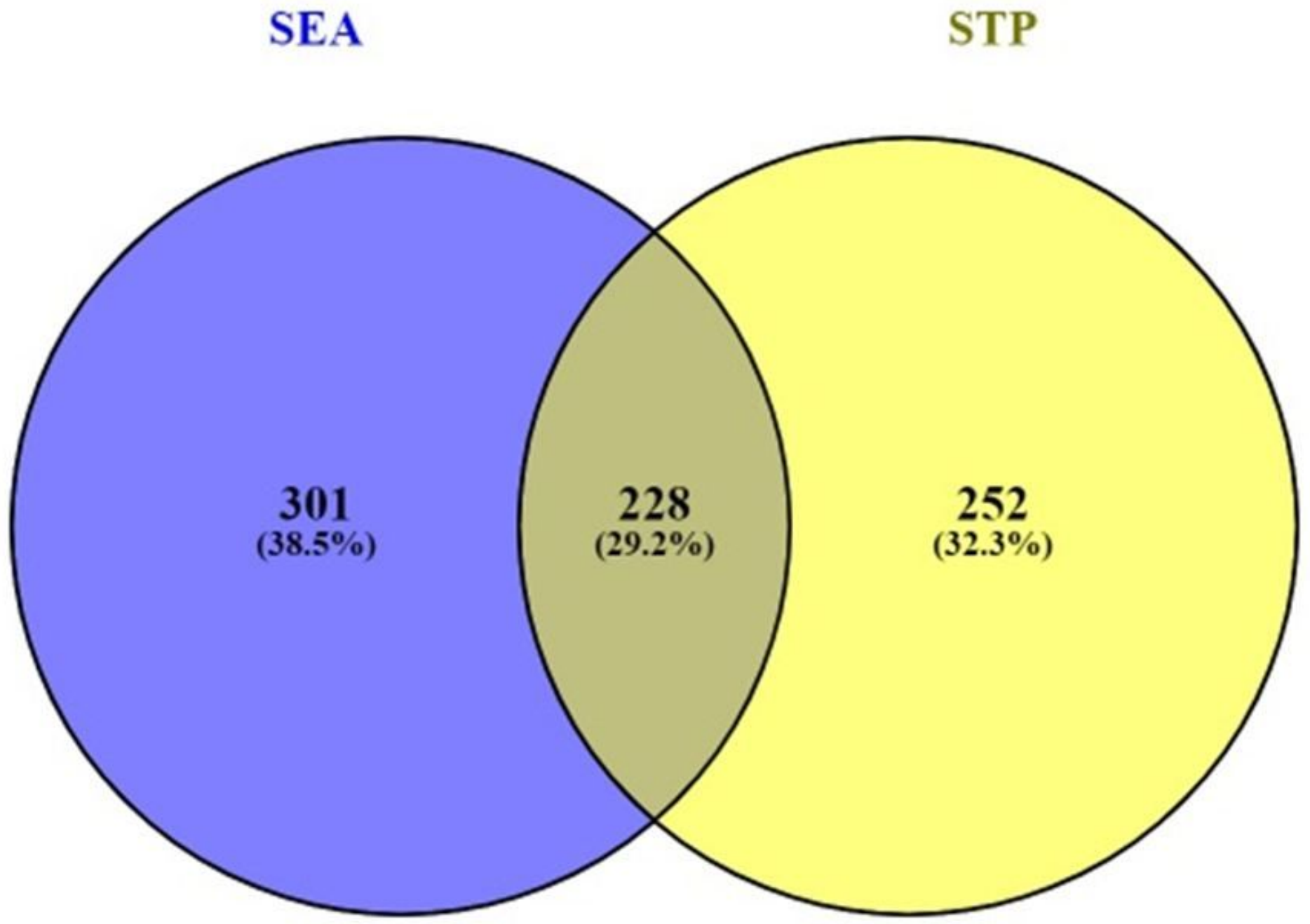

Figure 4 
Overlapping genes (228 genes) of NSAIDs related genes identified from SEA (529 genes) and STP (480 genes).

A

B

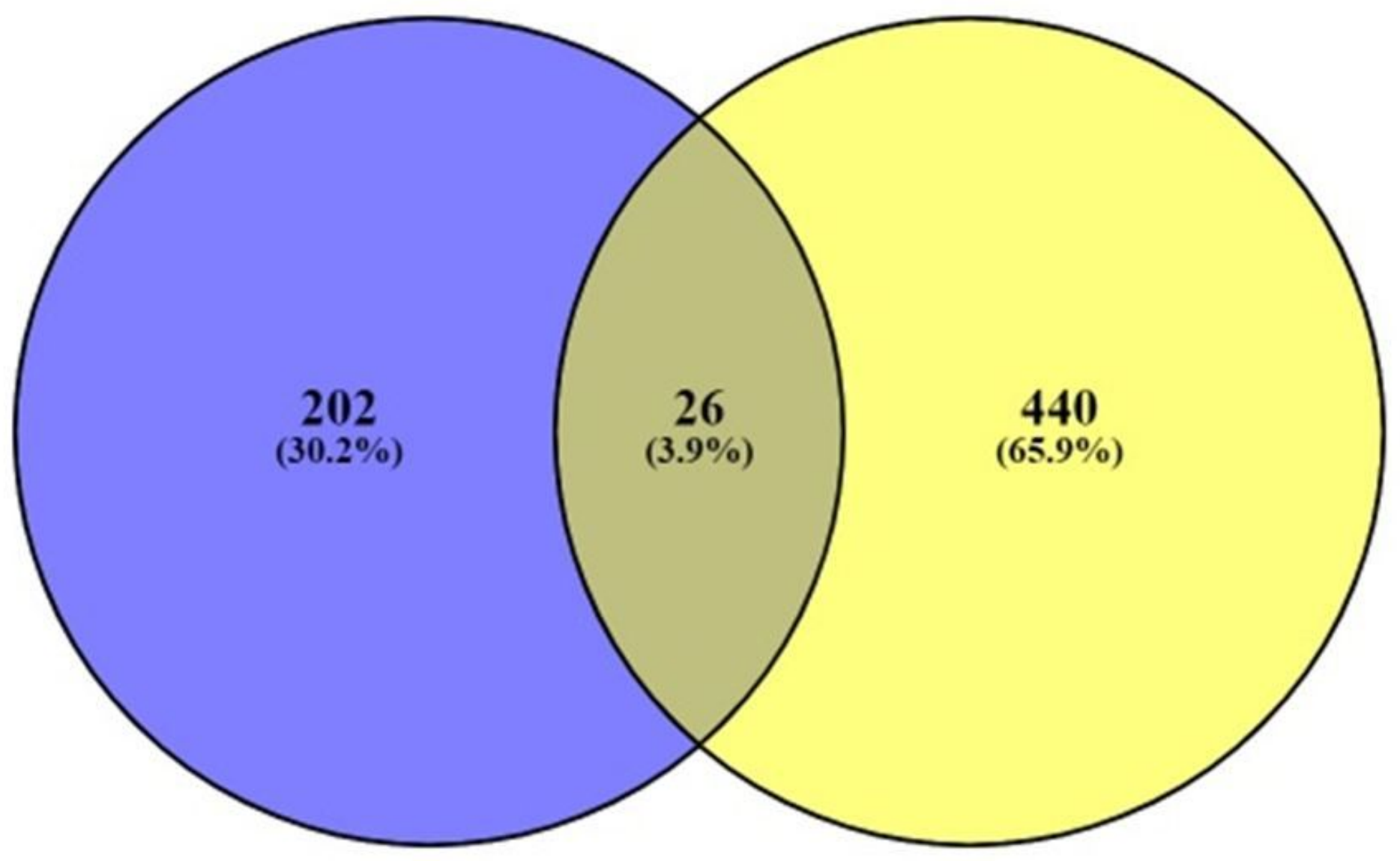

Figure 5

Overlapping genes (26 genes) between NSAIDs related 228 overlapped genes (A) and COVID-19 related 466 genes (B). 


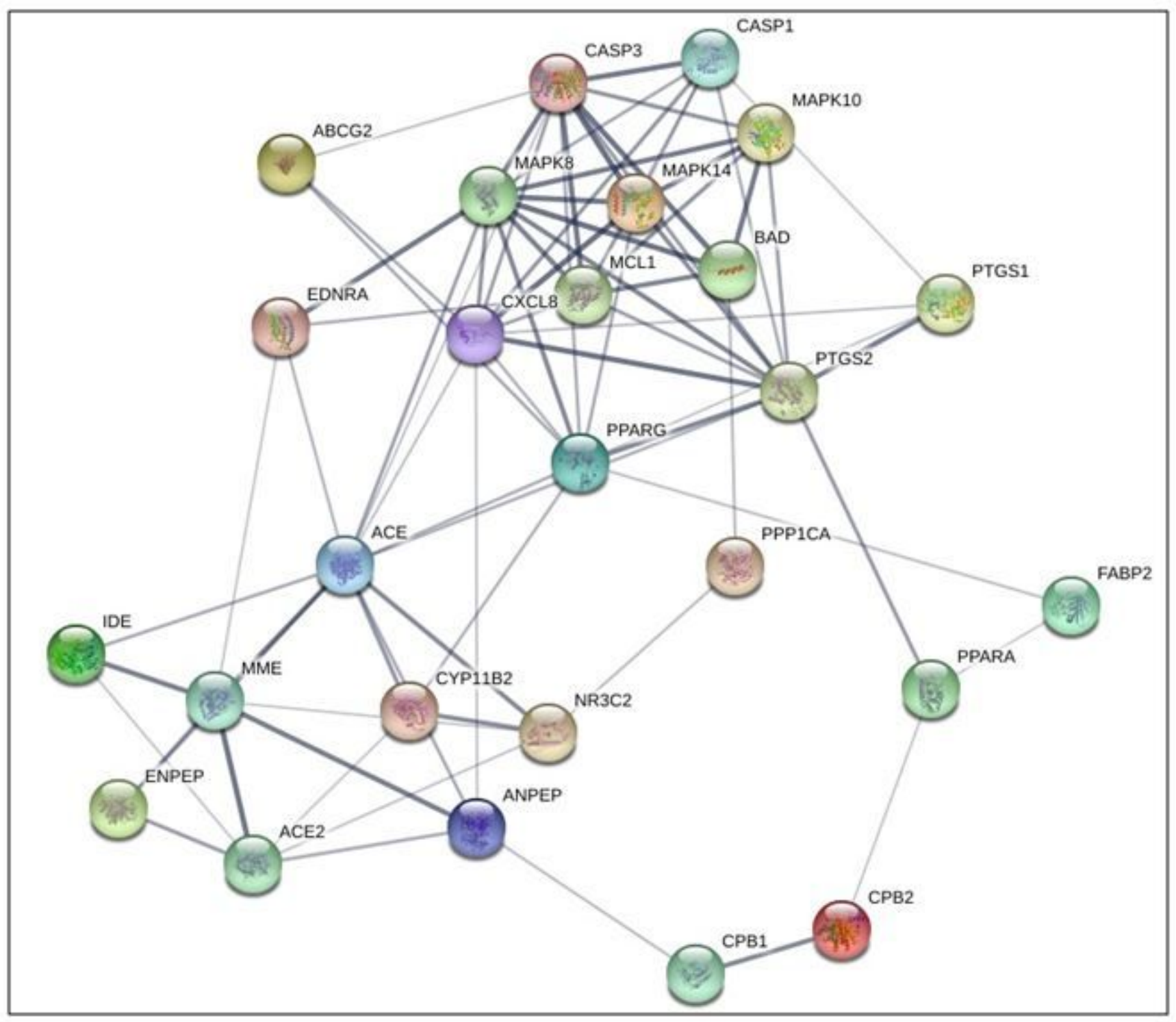

Figure 6

Gene-gene interaction with 26 nodes and 78 edges in NSAIDs against COVID-19 via STRING analysis. Node: The number of networks of compounds Edge: The number of interactions between compounds and genes 


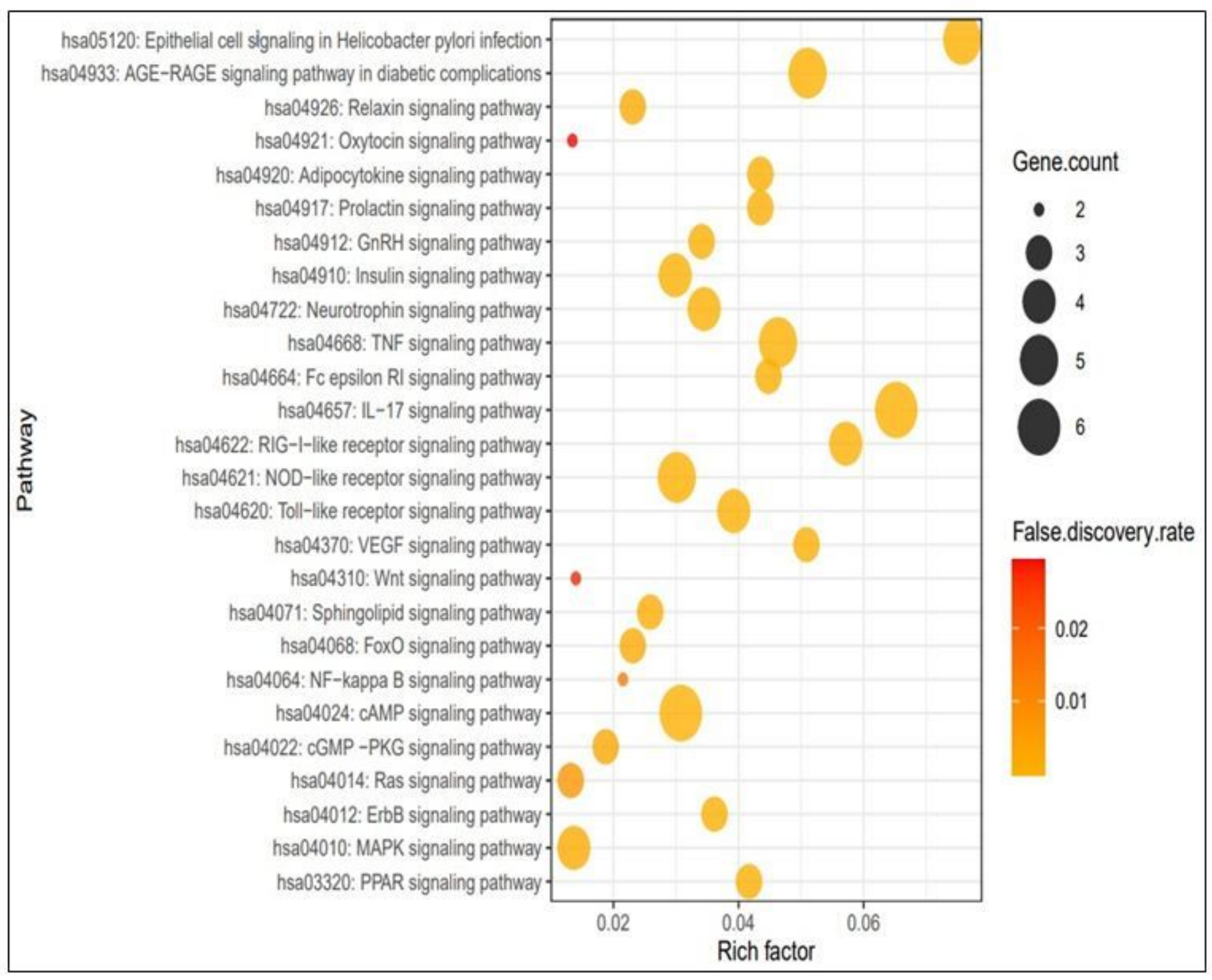

\section{Figure 7}

Bubble chart of 26 signaling pathways related to the occurrence and progression of COVID-19. 


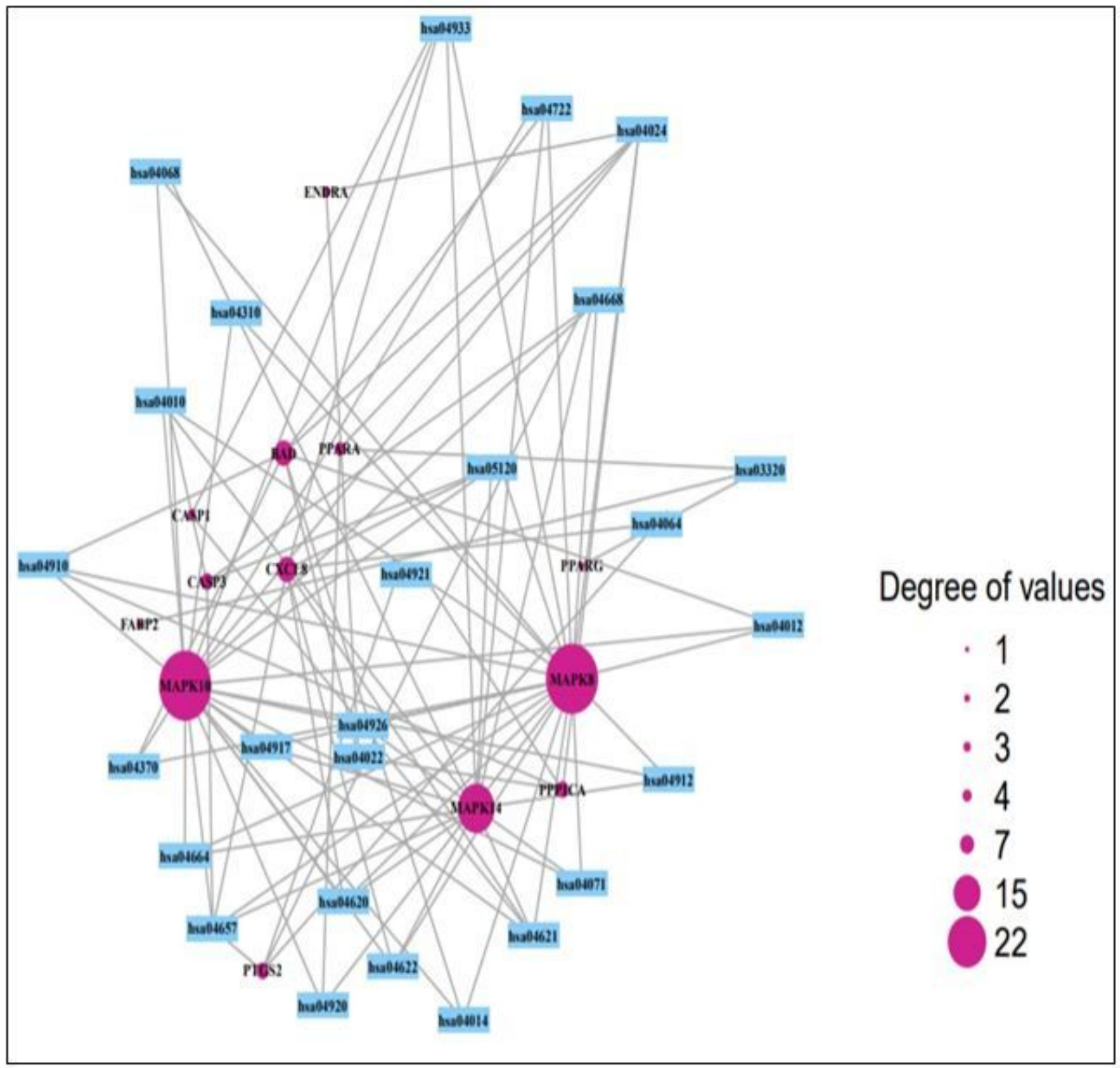

Figure 8

Degree values of 12 genes associated with KEGG pathway in 26 signaling pathways. Degree value: The number of KEGG ID interacted with gene. 

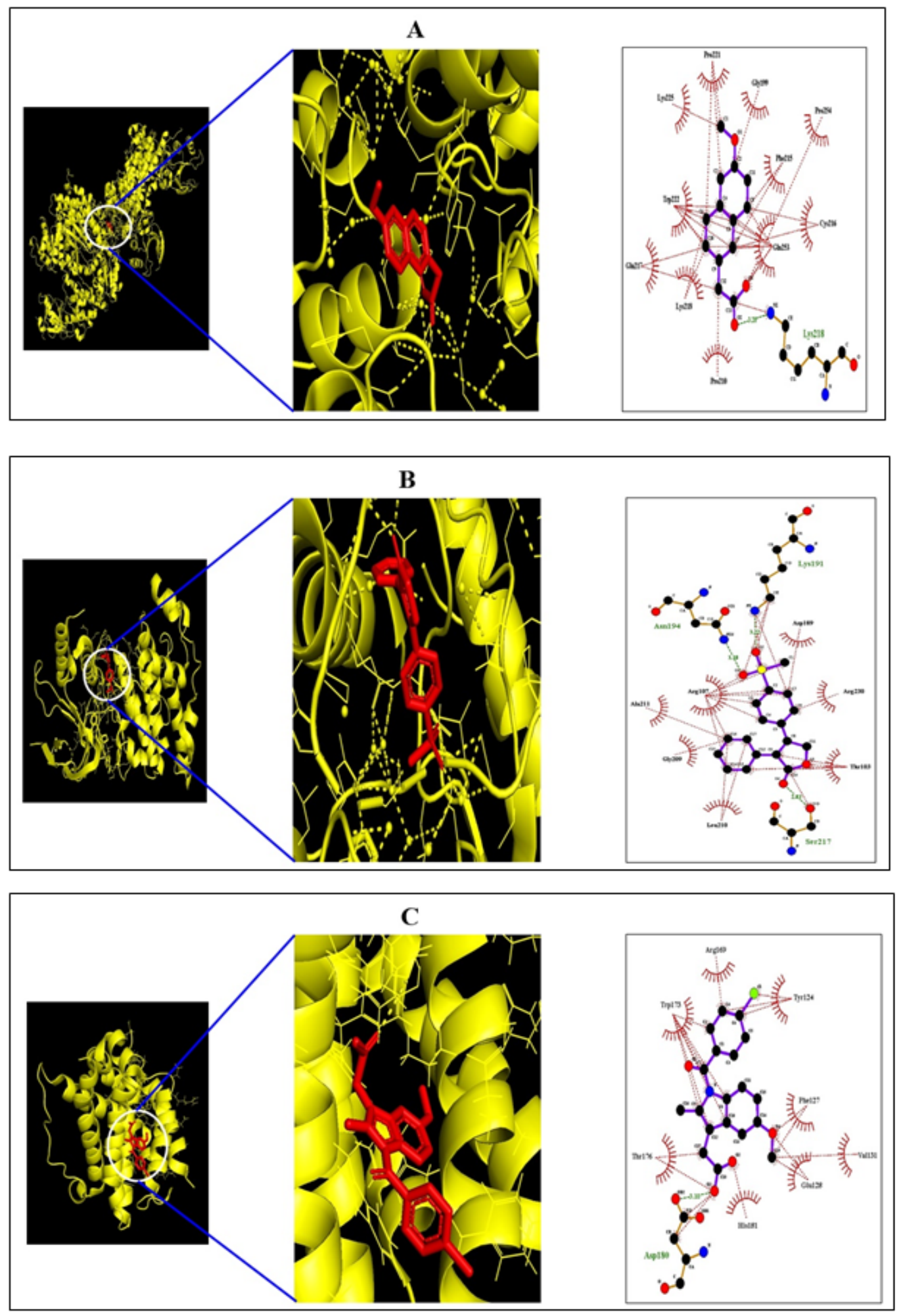

Figure 9

Molecular docking interaction between best docked NSAIDs and target proteins. (A) 6MNA on 4YR8 (B) Rofecoxib on 3TTJ (C) Indomethacin on 1G5J 


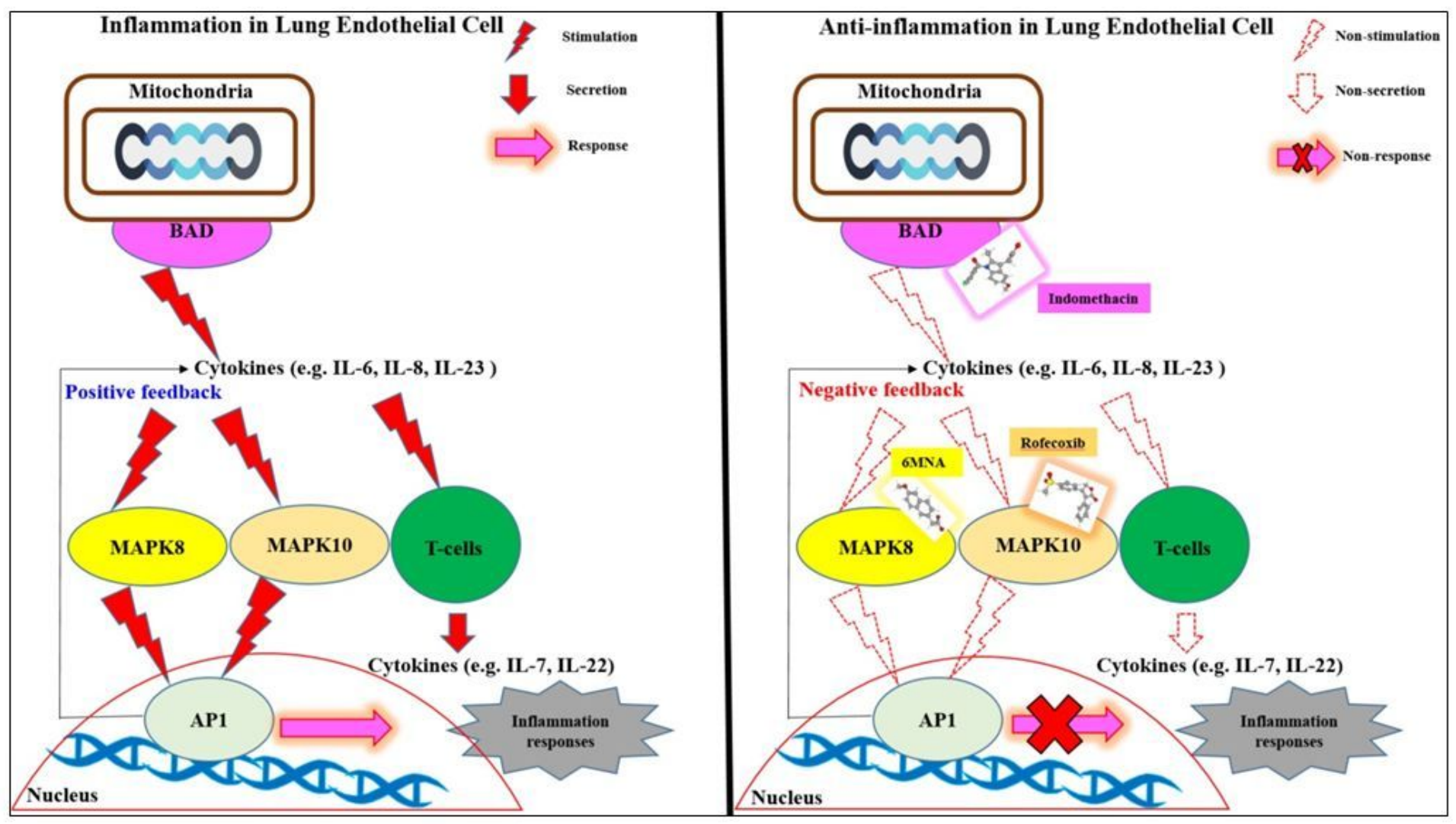

Figure 10

Anti-inflammation mechanisms of promising NSAIDs against COVID-19

\section{Supplementary Files}

This is a list of supplementary files associated with this preprint. Click to download.

- SupplementaryFigureS1.pdf

- SupplementaryFigureS1.pdf

- SupplementaryTables1.pdf

- SupplementaryTables1.pdf

- SupplementaryTables2.pdf

- SupplementaryTables2.pdf

- SupplementaryTableS3.pdf

- SupplementaryTables3.pdf

- SupplementaryTables4.pdf

- SupplementaryTableS4.pdf 